\title{
KINEMATIC MODELLING AND ANALYSIS OF SERIAL MANIPULATOR
}

\author{
Simona Domazetovska, Hristijan Mickoski, Marjan Djidrov \\ Faculty of Mechanical Engineering, "Ss. Cyril and Methodius" University in Skopje, \\ Karpoš II bb, P.O. box 464, 1001 Skopje, Republic of North Macedonia \\ simona.domazetovska@mf.edu.mk
}

\begin{abstract}
A b s t r a c t: The purpose of this paper is modelling and simulation of serial manipulator type with four rotating joints (RRRR). CAD model was developed by using the software SolidWorks for modelling the serial manipulator. Simulation model of serial robot is made by conversion from SolidWorks to Matlab/Simulink. The serial robot can be shown schematic as a kinematic connection of rigid bodies that are interconnected using rotary kinematic pairs. The manipulator movement is defined so the movement of each member is related to the previous one. The position and orientation of the gripper must be defined to ensure safe handling. In this paper, the steps needed to model the serial manipulator together with all its components, its transfer into Simulink and its Proportional Integral Derivative (PID) controlling and simulation is described. The obtained results for velocity and acceleration in kinematic pairs contribute in detailed analysis of kinematics and control design.
\end{abstract}

Key words: serial robots; serial robot kinematics; manipulator; PID control

\section{КИНЕМАТСКО МОДЕЛИРАЊЕ И АНАЛИЗА НА СЕРИСКИ МАНИПУЛАТОР}

А п с т р а к т: Целта на овој труд е моделирање и симулација на сериски робот со четири ротирачки зглобови (РPPP). Моделот CAD е изработен во програмскиот пакет SolidWorks со цел моделирање сериски робот. Извршена е симулација во програмскиот пакет Matlab/Simulink. Имитационен модел на сериски робот е добиен со префрлање на моделот од SolidWorks во програмскиот пакет Matlab/Simulink. Серискиот робот може да биде анализиран како кинематска врска на крути тела кои меѓусебно се поврзани со ротирни или кинематски парови. Движењето на роботот се дефинира така што се дефинираат движењата на секој член во однос на претходниот. За да се обезбеди сигурна манипулација во просторот, потребно е да се дефинира положбата и ориентацијата на фаќачот. Во овој труд целосно се дефинирани и опишани сите чекори потребни за моделирање на овој робот заедно со сите негови составни делови, негово префрлање во програмскиот пакет Matlab/ Simulink и управување преку пропорционална потполно деривирана (изведена) контрола (PID-контрола) и симулација. Добиените резултати за брзините и забрзувањата во неговите кинематски врски служат за детална анализа на кинематиката и контрола на движењето.

Клучни зборови: сериски робот; кинематика на сериски робот; манипулатор; PID-контрола

\section{INTRODUCTION}

Computer modelling, simulation and implementation tools have been widely used to support and develop nonlinear control, robotics, and MATLAB/SIMULINK courses. MATLAB with its toolboxes such as SIMULINK [1] is one of the most accepted software packages used by researchers to enhance teaching the transient and steady-state characteristics of control and robotic courses [2].
The international organization defines the robot as an automatically controlled, reprogrammable, multipurpose manipulator with three or more axes. Robot manipulator is a collection of links that connect to each other by joints, these joints can be revolute and prismatic that revolute joint has rotary motion around an axis and prismatic joint has linear motion around an axis [3]. Each joint provides one or more degrees of freedom (DOF). From the mechanical point of view, robot manipulator is 
divided into two main groups, which called; serial robot links and parallel robot links. In serial robot manipulator, links and joints is serially connected between base and final frame (end-effector).

Most of industrial robots are serial links and can be used as surgical robot and space robot manipulator.

Kinematics is an important subject to find the relationship between rigid bodies and end-effector in robot manipulator. Kinematic modelling of robots benefits the industrial automation processes by making them semi-autonomous or even fully autonomous. Because of the task nature and operational environment, the industrial robots are usually composed up of series of rigid links mounted on a base. A 6-Degree of Freedom (DOF) robotic arm manipulator is widely used in the industry. The most common applications of industrial robots include Spot welding, Spraying, Assembling and Manufacturing. Many of these applications actually require accomplishment of pick and place task. Implementation of this task fundamentally requires having the kinematic model of the robotic arm being active.

The forward kinematic model predicated on Denavit Hartenberg (DH) parametric scheme of serial robot arm position placement using Robotics toolbox is analyzed by the researchers in [4]. Given the desired position and orientation of the robot endeffector, the realized kinematics model provides the required corresponding joint angles. In the area of robot modelling and simulation, kinematics is a widely researched topic. The robot modelling and analysis techniques are typically based on line transformation or on point transformation. Clothier et al. [5] proposed a geometric model to solve the unknown joint angles required for autonomous positioning of a robotic system. In [6] is presented a method for forces and moments determination in kinematic joints of a three-member manipulator analytically by using the Lagrangian second-order equation and the principle of virtual work. Sahu et al. [7] derived a new method, quaternion algebra, for solution of forward kinematic problem. Popovic et al. [8] developed a strategy to analyze the upper extremity movement of the arm, while complete Wang et al. [9] presented body kinematics of a radial symmetrical six legged robot. Kinematic analysis of a new type of hybrid (parallel-serial) robot manipulator, consisting of two serially connected parallel mechanisms were analyzed in [10].

A method for solving the complete dynamic problem in serial robots with rigid links and ideal joints using the Gibbs-Appell equations as starting point is presented in [11].
The researchers in [12] present a new formulation method to solve kinematic problem of serial robot manipulators, aiming to formulize inverse kinematic problem in a compact closed form to avoid singularity problem. The main targets in designing control systems are stability, good disturbance rejection, and small tracking error [13]. Several industrial robot manipulators are controlled by linear methodologies [e.g. Proportional Derivative (PD) controller, Proportional Integral (PI) controller or Proportional Integral Derivative (PID) controller].

Modelling and simulation of serial manipulator, type RRRR (rotation, rotation, rotation, rotation) will be analyzed in this work. For this purpose, CAD modelling in Solid Works and modelling and simulation of the behaviour of the serial manipulator in Matlab/Simulink will be analyzed. PID control will be applied to the manipulator in order to control the robot.

\section{MODELLING OF THE SERIAL ROBOT IN SOLID WORKS}

Modelling of different systems is a process of creating appropriate model of the analyzed system thus, all the necessary research and teaching of the system can be performed on the model, rather than on a real system. The process of modelling systems is important stage while researching in terms of reducing the time and resources. The simulation is not a method to make an optimal solution, but provides an opportunity to evaluate the quality of the system relative to another.

Modelling of the parts and their kinematic pairs was analyzed in SolidWorks. In order to understand and develop the properties of serial robots, a model of a serial manipulator (Figure 1) was developed and based on this model direct kinematics is presented.

As it can be seen from Figure 1, the serial robot has a functional and a simple structure. The model is consisted of six individual parts that are connected through kinematic pairs, creating a compact structure of serial manipulator. The components of which the robot is consisted are:

- base, which is attached to the work surface,

- rotational joints which allows one degree rotation of the robot,

- connection part, that enables the second rotation of the robot and has a larger dimension, so it can allow larger working space, 
- cylindrical part that allows the third rotation of the manipulator. It has a cylindrical recess which enables translation of the connected kinematic pair,

- piston section, which enables increasing of the working space,

- gripper, the executive member, located at the end of the robot's structure in order to perform the certain mission.

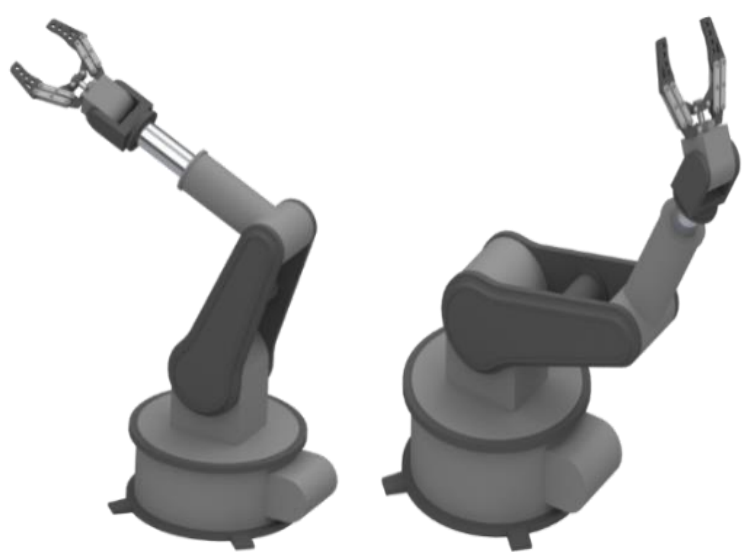

Fig. 1. Structure of the serial robot modelled in Solid Works

Due to the greater stability required to ensure high accuracy of the gripper, four support parts are placed at an angle of $90^{\circ}$ to eachother. The robots control interface is attached on the base consisted of electronics. The material and dimension of the base are chosen according to the required performance.

The rotary part is composed of a cylinder that has the same dimensions as the cylindrical opening of the base. Using the mate tool, the rotary part is connected with the base. The robustness and reliability of the serial manipulator while increasing the working space are one of the things that have to be considered while modelling.

The cylindrical part is consisted of two mutually normal cylindrical openings. The opening of the cylinder part is intended to form a piston mechanism, whose main achievement is to increase the robot's working space. The piston part is composed of a cylinder, a circular heat for limitation of the movement and holder for the gripper. The gripper is the last link from the serial robot, which structure is shown on Figure 2.

All of the previous parts actually serve to position the gripper to the required location of performance. The gripper is the most complex part of the serial manipulator, composed of many parts that form one functional structure. The structure allows performing movements of the gripper through cylindrical axis located in the middle, hydraulic driven. The movement of the gripper is transferred through the mechanisms.

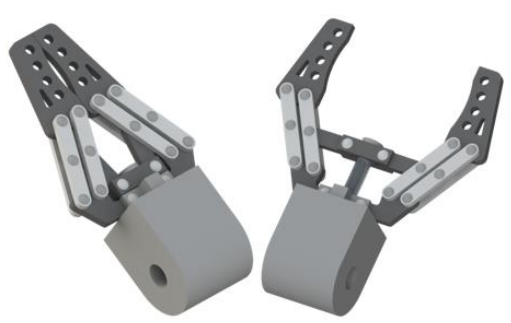

Fig. 2. CAD model of the gripper

Figure 3 shows a schematic representation of the serial robot, showing all of its parts along with the provided manoeuvres. The workspace is relatively high, allowing the gripper manipulating away from the base with great accuracy.

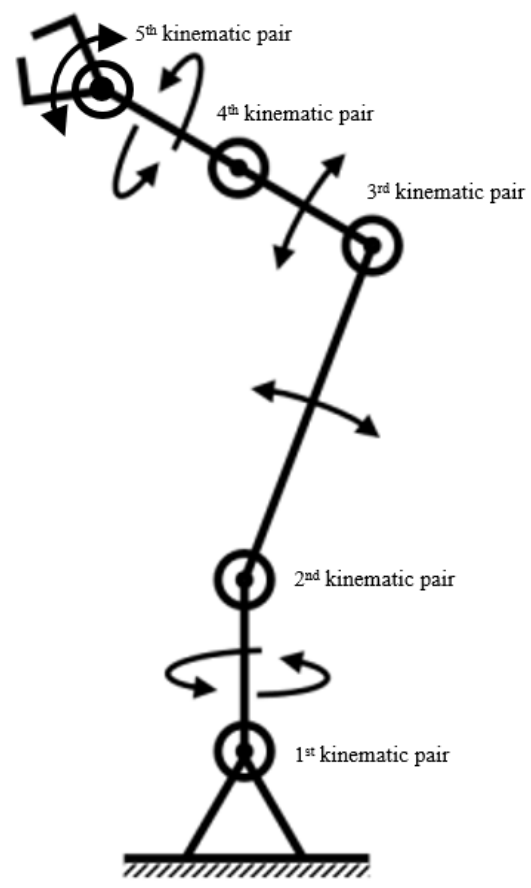

Fig. 3. Schematic representation of the serial manipulator

\subsection{Direct kinematics modelling}

Denavit-Hartenberg's method is an efficient procedure for the determination of direct kinematics, widely used in robotic applications. In order to calculate the direct kinematic equations for an open chain manipulator, it is necessary to derive and define a relative position and orientation of two consecutive links. While solving the kinematics of the links, relationship between the two parts has to be defined. 
The axis $i$ is defined for the connections of the parts $i-1$ and $i$.The axis of the joint $i+1$ is chosen, and the point $O_{i}$ is located between the intersection of the $z_{i}$ axis with the normal segment to the $z_{i-1}$ and $z_{i}$ axes. Axis $x_{i}$ is defined which has the same direction as the drawn segment and at the same time is normal on the z-axis. In order to complete the coordinate systems, axis $y_{i}$ is selected.
Once the kinematic parameters are defined, the transformation between the $i-1$ and $i$ coordinate systems can be expressed.

The homogeneous transformation matrix for the chosen system in the selected coordinate system will be:

$$
A_{i}^{i-1}\left(\begin{array}{cccc}
\cos (\theta i) & -\sin (\theta i) & 0 & 0 \\
\sin (\theta i) & \cos (\theta i) & 0 & 0 \\
0 & 0 & 1 & d_{i} \\
0 & 0 & 0 & 1
\end{array}\right)
$$

If the selected system is moved from its position along the $x$-axis, the position is rotated for angle $\alpha_{i}$ along the $x$-axis. The new position will match with the new position of the coordinate system $i$. Its homogeneous transformation matrix will be:

$$
A_{i}^{i^{\prime}}\left(\begin{array}{cccc}
1 & 0 & 0 & \alpha_{i} \\
0 & \cos \left(\alpha_{i}\right) & -\sin \left(\alpha_{i}\right) & 0 \\
0 & \sin \left(\alpha_{i}\right) & \cos \left(\alpha_{i}\right) & 0 \\
0 & 0 & 0 & 1
\end{array}\right)
$$

The resulting transformation of the coordinate system is obtained by multiplying the individual homogeneous transformations:

$$
A_{i}^{i-1}\left(q_{i}\right)=A_{i}^{i-1} A_{i}^{i^{\prime}}\left(\begin{array}{cccc}
\cos \left(\theta_{i}\right) & -\sin \left(\theta_{i}\right) \cos \left(\alpha_{i}\right) & \sin \left(\theta_{i}\right) \sin \left(\alpha_{i}\right) & \alpha_{i} \cos \left(\theta_{i}\right) \\
\sin \left(\theta_{i}\right) & \cos \left(\theta_{i}\right) \cos \left(\alpha_{i}\right) & -\cos \left(\theta_{i}\right) \sin \left(\alpha_{i}\right) & \alpha_{i} \sin \left(\theta_{i}\right) \\
0 & \sin \left(\alpha_{i}\right) & \cos \left(\alpha_{i}\right) & d_{i} \\
0 & 0 & 0 & 1
\end{array}\right)
$$

The Denavit-Hartenberg method allows the definition of kinematic functions by combining individual homogeneous transformations into a resultant transformational matrix. This procedure can be applied to any open kinematic chain.

\section{ANALYTICAL MODELLING OF SERIAL ROBOT}

The behaviour of physical systems in many situations may better be expressed with an analytical model. Modelling a robot involves study of its kinematic behaviour. A kinematic model is concerned with the robot's motion without considering forces producing the motions. The Simulink programming package is part of Matlab and has a great application in the technique and serves for modelling, simulation and analysis of dynamic systems in multiple areas. It can work with non-linear and linear systems in discrete and continuous time and explore the impact in the real models, which are real phenomena and affect the real model. Simulink uses a block library that, with a simple drag-and-drop procedure, ships into a separate window for a model and with appropriate blocking of the blocks, a model is created that can be easily repaired and updated later on. It is connected to the Matlab tools and has instant access to them, so Simulink models can be easily analyzed and visualized. Once the Solid Works model is developed, in order to perform a simulation, it should be transferred to Matlab/Simulink which is enabled automatically by the Multibody tool provided by MathWorks. The basic criteria needed to be established are: the program compatibility, installation files, connectivity, solid model support and model export. The Matlab/ Simulink model of the serial robot is shown on Figure 4.

The simulation of the gripper is created as an imitation model independent of the previous one, modelled due to its functionality in Matlab. The controlling of the gripper is performed due to the geometry of the two parts of the gripper, rotated for $45^{\circ}$, in order to achieve closing of the gripper. Figure 5 shows the visual look and the Simulink model of the gripper. 

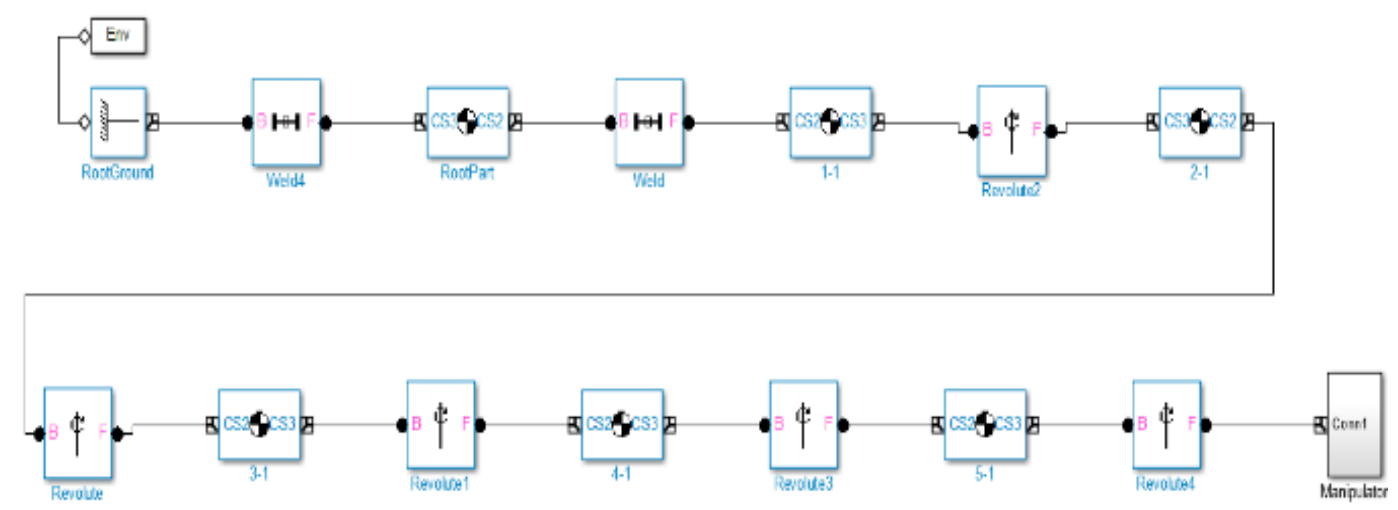

Fig. 4. Matlab/Simulink model of the serial robot

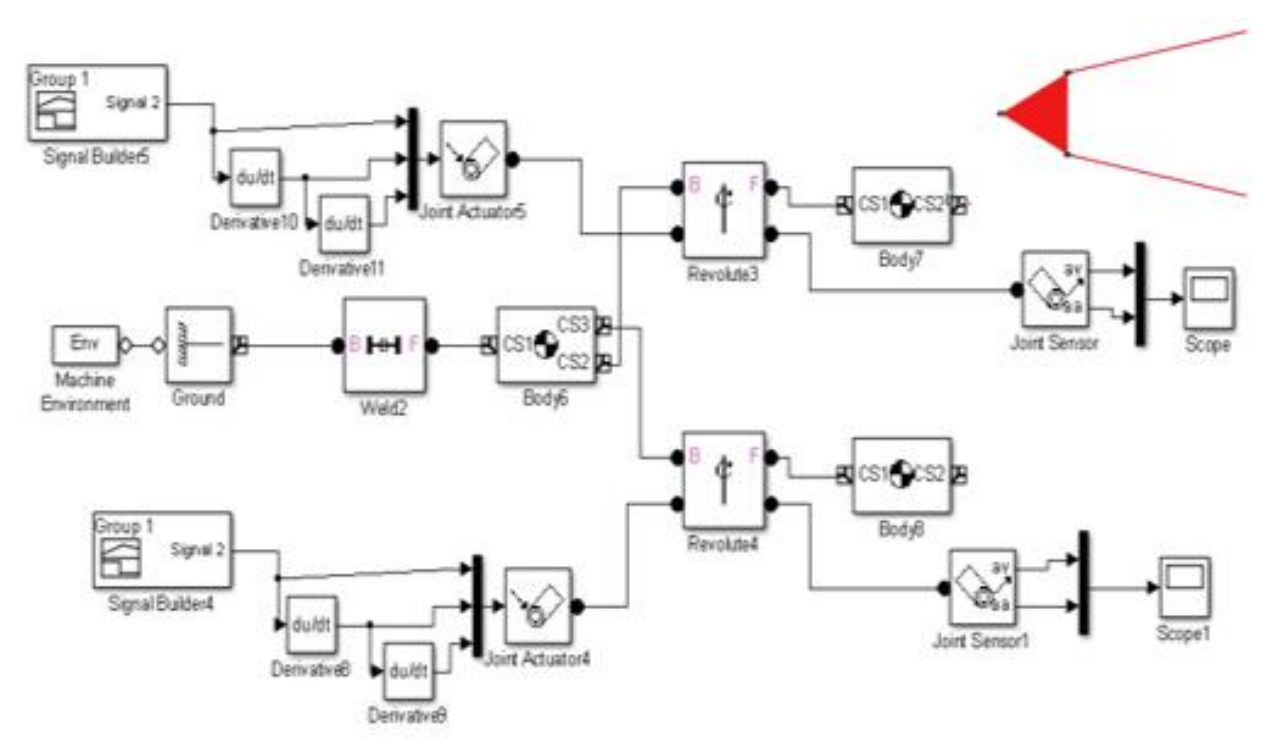

Fig. 5. Matlab/Simulink model of the gripper

\section{PID CONTROL}

PID (Proportional Integral Derivative) controllers use a control loop feedback mechanism to control process variables and are the most accurate and stable controller. PID integral differential method is the expansion of simpler PD management. Enlargement is done by adding an integral component. Adding this component substantially reduces the positional error in the joints of and it is approximate to zero.The PID law is represented by the following equation:

$$
\mathrm{u}(\mathrm{t})=K_{p} e(t)+K_{i} \int_{0}^{t} e(t) d t+K_{d} \frac{d_{e}(t)}{d t}
$$

where $K p$ is a proportional amplifier, $K_{d}$ is a differrential amplifier and $K_{i}$ is a integration amplifier.

The connection of the PID controller to Simulink simulated models is very useful and effective. Since the wanted motion is initiated in kinematic pairs, the actuator block is linked to the kinematic link between two rigid bodies. In order to have control accuracy data, a kinematic relationship sensor is set which measures displacements, velocity and acceleration. To assign a value to the management, a step function is used which is passed through one slider and will have values from $-100^{\circ} \div$ $130^{\circ}$, and it can be real-time during the simulation to change and in that way to perform planned control in real time. The sum of the two values is deducted by the return function representing the error and thus controlling the accuracy of the entire system. The controlling of the system in Matlab/Simulink is shown on Figure 6.

Individual PID controllers can operate independently in relation to each other and this is their great advantage. It is possible to generate a force in a kinematic pair and thus move one part of the robot, while the previous parts remain stationary. 


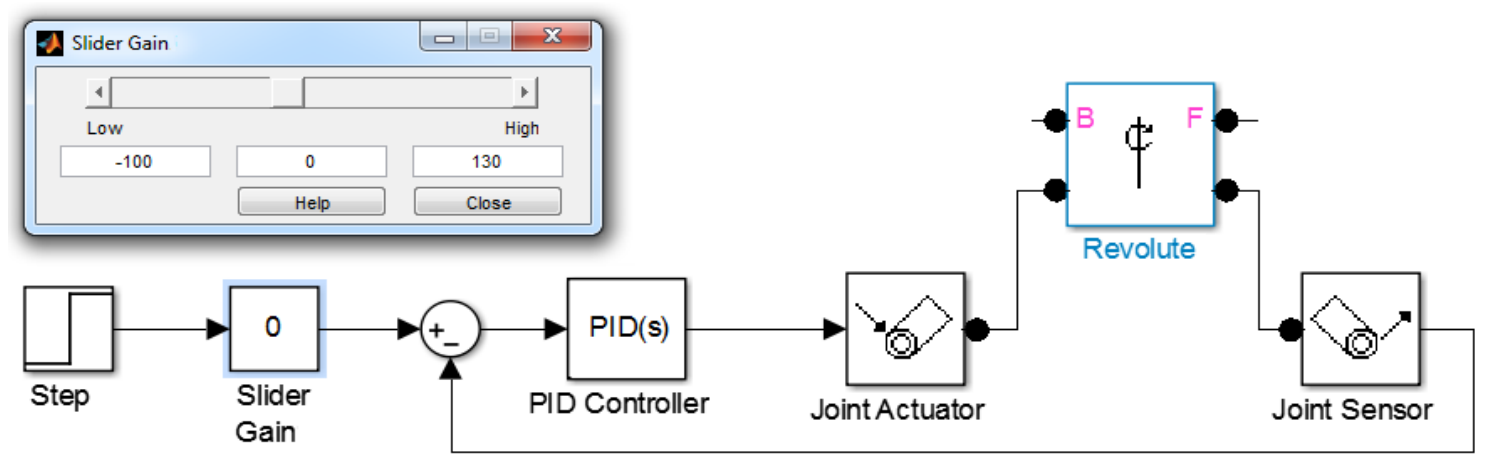

Fig. 6. PID control of the serial manipulator

\section{RESULTS}

The velocity and acceleration of each of the kinematic pairs are analyzed. The results of the measured data are shown on a graph for each kinematic pair separately. The serial robot requires fivesuch structures that are placed in the model and tested. The results for the five parts are shown on Figure 7.

After applying control on the manipulator's gripper, the results for the velocity and acceleration are analyzed, shown on Figure 8.

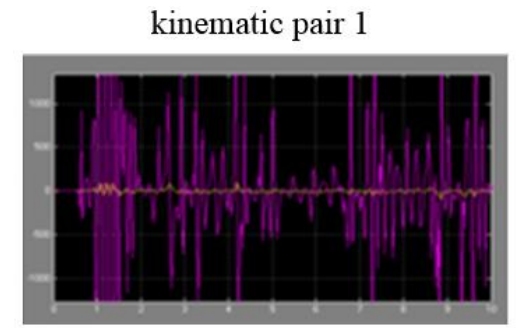

[s]

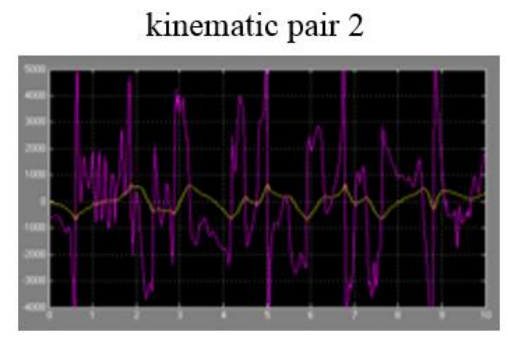

$[\mathrm{s}]$

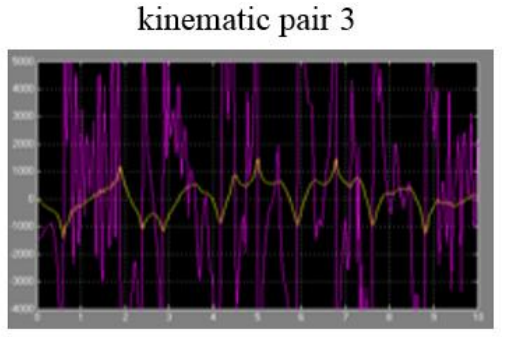

$[\mathrm{s}]$

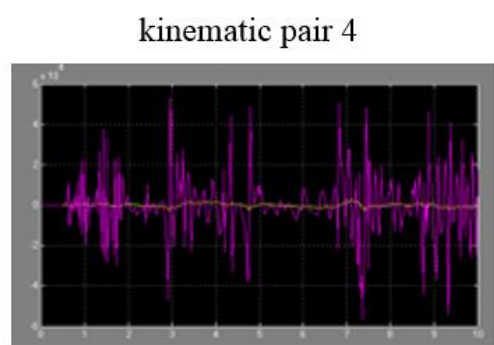

[s]

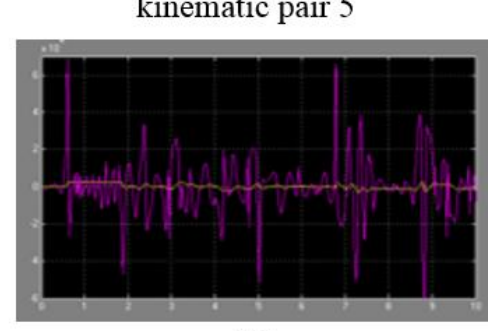

[s]

Fig. 7. Velocity and acceleration results for each of the kinematic pairs

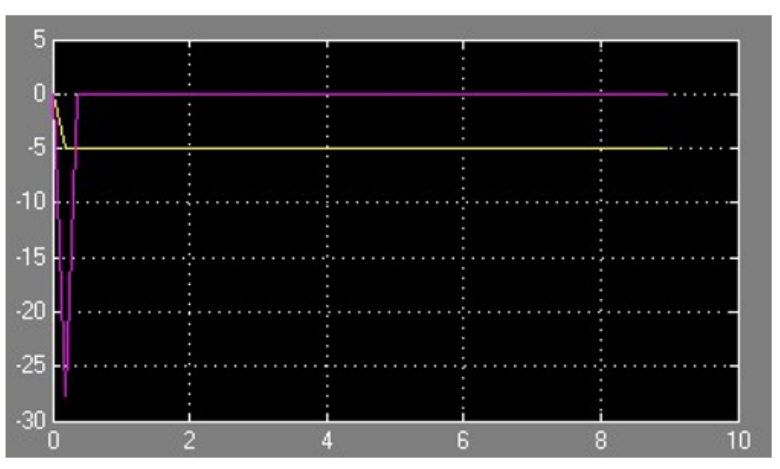

$[\mathrm{s}]$

Fig. 8. Velocity and acceleration - results for the gripper

\section{CONCLUSION}

Modelling and simulation of robotic systems using various software reflects the process of designing, constructing and controlling robots in the real world. Simulating the dynamic processes provides an overview of the behaviour of the existing dynamic system with proper management. Simulation is of great importance because with it the constructors can presume and evaluate the behaviour of the robot, as well as to confirm and optimize the robot movement plan for the given problem. The simulation significantly reduces the time and costs 
that are unavoidable in experimental research of dynamic systems, and plays an important role in the evaluation of production.

The presented serial robot manipulator has been kinematically modelled followed by the analysis of its workspace and for the modelling of the robot SolidWorks and Matlab softwares were used. Forward kinematic model has been validated by using Matlab and PID controlling was used to control the serial robot manipulator.

The possibility of simulation opens up a wide range of opportunities for creative solving of many problems. Serial manipulators are more and more used in industry, and in environments that are inaccessible or risky for humans. Their simple structure made up of rotary and translator kinematic pairs allows the executive member to easily position and orient in the workspace. They work with great accuracy and speed, in places that require great precision and responsiveness.

\section{REFERENCES}

[1] Kurfess, T. R.: Robotics and Automation Handbook. CRC Press, 2004.

[2] Ogata, K.: Modern Control Engineering (pp. 6142-6143). Upper Saddle River, NJ, Prentice Hall, 2009.

[3] Piltan, F., Emamzadeh, S., Hivand, Z., Shahriyari, F., Mirazaei, M.: PUMA-560 robot manipulator position sliding mode control methods using MATLAB/SIMULINK and their integration into graduate/undergraduate nonlinear control, robotics and MATLAB courses. International Journal of Robotics and Automation, 3 (3), 106150 (2012).

[4] Iqbal, J., Islam, R. U., Khan, H.: Modelling and analysis of a 6 DOF robotic arm manipulator. Canadian Journal on
Electrical and Electronics Engineering, 3 (6), 300-306 (2012).

[5] Clothier, K. E., Shang, Y.: A geometric approach for robotic arm kinematics with hardware design, electrical design, and implementation. Journal of Robotics, Volume 2010, Article ID 984823, 10 pages, http://dx.doi.org/10.1155/2010/984823

. [6] Mickoski, H., Mickoski, I., Djidrov, M.: Dynamic modelling and simulation of three-member robot manipulator. Mathematical Models in Engineering, Vol. 4 Issue 4, pp. 183-190 (2018).

[7] Sahu, S., Biswal, B. B., Subudhi, B.: A novel method for representing robot kinematics using quaternion theory, 2008.

[8] Popovic, N., Williams, S., Schmitz-Rode, T., Rau, G., Disselhorst-Klug, C.: Robot-based methodology for a kinematic and kinetic analysis of unconstrained, but reproducible upper extremity movement. Journal of Biomechanics, 42 (10), 1570-1573 (2009).

[9] Wang, Z., Ding, X., Rovetta, A., Giusti, A.: Mobility analysis of the typical gait of a radial symmetrical sixlegged robot. Mechatronics, 21 (7), 1133-1146 (2011).

[10] Tanev, T. K.: Kinematics of a hybrid (parallel-serial) robot manipulator. Mechanism and Machine Theory, 35 (9), 1183-1196 (2000).

[11] Mata, V., Provenzano, S., Valero, F., Cuadrado, J. I.: Serial-robot dynamics algorithms for moderately large numbers of joints. Mechanism and Machine Theory, $\mathbf{3 7}$ (8), 739-755 (2002)

[12] Sariyildiz, E., Temeltas, H.. Solution of inverse kinematic problem for serial robot using dual quaterninons and Plücker coordinates. In 2009 IEEE/ASME International Conference on Advanced Intelligent Mechatronics, IEEE, 2009, July, pp. 338-343.

[13] Kieffer, J.: A path following algorithm for manipulator inverse kinematics. In: Proceedings. IEEE International Conference on Robotics and Automation, IEEE, 1990, May, pp. 475-480. 
